\title{
Subjektīvā drošības uztvere - izpētes ietvara konstruēšana
}

ŽANETA OZOLIN,A, IVETA REINHOLDE, SIGITA STRUBERGA

Nodaḷā atspoguḷoti drošības subjektīvās uztveres izpētes svarīgākie metodolog̣iskie aspekti, kuri izmantoti Latvijas iedzīvotāju viedokḷu noskaidrošanai empīrisko datu ieguvē. Drošības izzināšanai Latvijā ir senas tradīcijas, tomēr tās subjektīvie aspekti nav pietiekami apzināti. Tiem ir īpaša loma laikā, kad valstī tiek ieviesta visaptverošā valsts aizsardzība, kurā iedzīvotāji ir ne tikai drošîbas patērētāji, bet arī radītāji. Izpētes metodologisko rāmējumu veido šādi secīgi soḷi: sabiedriskās domas apaujas rezultātu analīze, kas liecina par iedzīvotāju dominējošām attieksmēm pret drošību valstī, pētāmo drošības sektoru identificēšana, attiecīgu indikatoru izvēle katram no tiem, pārvaldības indikatoru noteikšana kopumā un atbilstoši katram sektoram, fokusa grupu interviju veikšanas ietvars, pašvaldības darbinieku intervēšana atbilstoši iegūtajiem datiem par subjektīvo uztveri attiecīgajā kopienā un rekomendāciju izstrāde, kas balstīta pētījumu rezultātos. Izstrādātais un lietotais Latvijas iedzīvotāju drošîbas subjektīvās uztveres metodologiskais rāmējums l̦auj iegūt dažādus datus indivīda, grupas, kopienas un valsts līmenī, tādējādi veidojot politiku, kura atbilst iedzīvotāju vajadzībām un rada nosacījumus iesaistei visaptverošā valsts aizsardzībā.

Atslēgvārdi: drošỉbas indikatori, metodologiija, pārvaldības indikatori, subjektīvā drošība, subjektīvā drošības uztvere.

The article focuses on the main elements of methodology applied in analysis of the subjective perception of security that is prevailing among the inhabitants of Latvia and discusses the subsequent collection of empirical data. The concept of security has been widely studied in Latvia and has longstanding traditions, while the subjective perspective of security has not been investigated and analysed. The subjective aspects of security are of particular importance at the present time when the government is introducing a comprehensive defence concept. This comprehensive defence concept presupposes that society acts not only as a consumer but also as a provider of security. 
The methodological framework consists of the following components: 1) analysis of existing public opinion polls that serve as a source of information on the dominant attitudes towards security in the country, 2) identification of the most relevant security sectors, 3) elaboration of indicators relevant in each of the sectors, 4) focus group interviews based on the set of indicators in selected municipalities, 5) further interviews with municipal employees based on the results of the focus group interviews, thus comparing whether local governments are aware of the subjective perceptions of security and whether adequate policy measures are being employed, and 6) recommendations based on the results of the study. The proposed methodological framework allows to collect rich data on the subjective perception of security at the individual, group, community, and national levels; this data can then be used for policy making that responds to the needs of inhabitants and engages them in the comprehensive defence of the country.

Keywords: governance indicators, methodology, security indicators, subjective security, subjective security perception.

\section{levads}

Latvijas iedzīvotāju drošības subjektīvās uztveres izpēte nav iespējama bez teorētiskā analīzes ietvara izstrādes, jo tas rada nosacījumus autoru pašu individuālo priekšstatu un zināšanu norobežošanai no iegūtajiem datiem un patvaḷịgas interpretācijas. Tādēḷ šìs nodaḷas mērķis ir secīgi konstruēt tādu metodolog̣isko rāmējumu, kas kalpotu visa projekta vajadzībām un būtu izmantojams empīrisko datu ieguvei un atlasei, uz kura pamata izstrādātu secinājumus un rekomendācijas. Pētījuma centrālais koncepts ir drošiba. Tādēl raksta pirmā daḷa ir veltīta šì jēdziena izpētes īpatnībām Latvijā un tā definējuma pamatojumam, kas izmantots visa pētījuma gaitā. Otrajā daḷā uzmanība pievērsta drošỉbas subjektīvās uztveres dažādiem aspektiem, kuri ir pētīti starptautiskās politikas jomā, un noteikti tie elementi, kuri nozīmīgi Latvijas gadījuma izpētē. Savukārt trešā raksta daḷa izskaidro galvenos izpētes soḷus, kas l̦auj nonākt līdz Latvijas iedzīvotāju drošības subjektīvās uztveres analīzes galvenajiem elementiem un to sasaistei ar drošības politikas veidošanu, ìpašu uzmanību pievēršot pašvaldību attiecībām ar kopienām. 


\section{Drošības jēdziena izpēte Latvijā starptautisko diskusiju kontekstā}

Drošības jēdziena izpēte Latvijā ir ar salīdzinoši senām tradīcijām. Tā ir viena no visvairāk pētītajām jomām starptautiskās politikas disciplīnā. Drošîbas dažādo sektoru izzināšanai uzmanību ir veltijuši, piemēram, vēstures, ${ }^{1}$ ekonomikas, ${ }^{2}$ starptautisko tiesību ${ }^{3}$ nozares pārstāvji. Taču tieši starptautiskās politikas disciplīnā ir vērojams visbagātākais pētijumu klāsts, un tam ir savi skaidri redzami objektīvi nosacijumi. Latvijas neatkarības atgūšana 1990.-1991. gadā bija primāri saistīta ar Krievijas karaspēka izvešanu, trauslā miera nodrošināšanu, pārejot uz demokrātisku politisko režīmu un Latvijas drošības un aizsardzības sistēmas veidošanu, tai skaitā dibinot Latvijas bruņotos spēkus no nulles punkta. Praktiski risināmie jautājumi, kuros nebija uzkrāts bagāts zināšanu kopums, veicināja pētījumu par drošîbu un drošības politiku nacionālā, regionālā un starptautiskā līmenī.

Salīdzinājumā ar drošỉbas pētījumiem pasaulē Latvijas pieredze un attīstības posmi neatbilst tai dinamikai, kas bija vērojama šajā nozarē pasaulē, kurā 1990. gada sākumā jau valdīja visdažādāko skolu konkurence par "vislabāko piedāvājumu" drošības skaidrojumu tirgū, sākot ar reālistu cinnu par intelektuālu izdzīvošanu pēc aukstā kara līdz konstruktīvistu piedāvājumam radīt jaunas drošības identitātes un skaidrot "runas aktus"'. Latvijas gadījumā

1 Skatīt, piemēram, Feldmanis, I., Stranga, A., Virsis., M. (1993). Latvijas ārpolitika un starptautiskais stāvoklis: 30. gadu otrā puse. Rīga: Latvijas Ārpolitikas institūts; Stranga, A. (2010). Vēsturnieki par Latvijas drošības problēmas risinājumiem starpkaru periodā. Latvijas Vēsture: jaunie un jaunākie laiki, Nr. 2, 22.-36. lpp.

2 Skatīt, piemēram, Šumilo, E., Baumane, I. (2007). Some Negative Aspects of Social Capital: The Case of Undeclared Work in Latvia. Humanities and Social Science in Latvia, No. 2(51). Riga: Institute of Economics; Sauka, A., Rivža, B. (red.) (2014). Latvijas ekonomikas un uzñēmējdarbības izaicinājumi. Ventspils: Ventspils Augstskolas Uzṇēmējdarbības, inovāciju un reǵionālās attīstības centrs.

3 Ziemele, I. (2004). Latvijas loma drošības un miera tiesiskā nostiprināšanā. Vai starptautiskām tiesībām un organizācijām ir nozīme? No: Latvija Eiropā: nākotnes vīzijas. Jundzis, T. (red.) Rīga: Latvijas Zinātṇu akadēmijas Baltijas stratēgisko pētījumu centrs, 31.-55. lpp.

4 Skatit: Wolfer, A. (1962). Discord and Collaboration: Esseys on International Politics. Baltimore: John Hopkins University; Morgenthau, H. J. (1967). Politics Among Nations. New York: Knopf; Bull, H. (1977). The Anarchical Society: A Study of Orderi $n$ World Politics. New York: Columbia University Press; Waltz, K. N. (1979). Theory of International Politics. New York: Random House; Ullman, R. H. (1983). Redifining Security. International Security, Vol. 8(1); Mearsheimer, J. (2001). The Tragedy of Great Power Politics. New York: Norton.

5 Buzan, B., Waever, O., de Wilde, J. (1998). Security: A New Framework for Analysis. Boulder Co: Lynne Rienner; Weldes, J. et al. (1999). Cultures of Insecurity: States, Communities, and the Production of Danger. Minneapolis: University of Minnesota Press; Jone, R. W. (1999). Security, Strategy and Critical Theory. Boulder Co: Lynne Rienner; McSweeney, B. (1999). Security, Identity and Interests. Sociology of International Relations. Cambridge: Cambridge University Press; Booth, K. (2005). Critical Security Studies and World Politics. Boulder Co: Lynne Rienner. 
pētniecību drošības jomā virzīja nevis globālās pārmaiṇas pasaules politikā un starptautiskajā spēku līdzsvarā, bet ikdienas praktiskie jautājumi, kas bija nozīmīgi Latvijas atgūtās neatkarības nostiprināšanai un tās neatgriezeniskuma nodrošināšanai, - drošības jēdziena skaidrojumi un nacionālās drošības politikas izveides aspekti, ${ }^{6}$ alianšu teorija, NATO būtỉba un paplašināšanos kavējošie un veicinošie nosacījumi, ${ }^{7}$ reǵionālā drošỉba kā Baltijas valstu un Baltijas jūras reg̣iona rīcība, ${ }^{8}$ un pāri šīm tēmām kā vienojošais izpētes objekts bija Krievijas rīcỉba pasaulē un reǵionālajā telpā. ${ }^{9}$

Latvijas drošības un aizsardzības politikas veidošana atstāja iespaidu uz pieaugošām atšķirībām drošības jēdziena teorētiskajos un empīiskajos pētỉjumos. Pēc aukstā kara beigām starptautiskās drošības pētijumos dominēja tā saucamie "visaptverošie drošības" aspekti - migrācija, atbruṇošanās, nevienlīdzības un nabadzības pieaugums, drošîba kā emancipācija un citi (atsauce uz 90. gadu sākuma pētijumiem), bet Latvijā šo tematu izpēte nesniegtu atbildes uz tūlītējiem jautājumiem par tradicionāliem drošỉbas sektoriem: nacionālo un militāro drošību, drošības politikas stratēǵiju - no neitralitātes līdz līdzsvarošanas politikai. Pētniecībā skatījums uz drošības politiku izlīdzinājās ap gadsimtu miju, kad no ES un NATO tika saṇemta skaidra atbilde par abu organizāciju paplašināšanās procesa uzsākšanu Baltijas valstīs. Līdz ar to Latvijas iekḷaušanai organizācijās, kuras bija valsts ārējās un drošības politikas mērḳis, bija nepieciešams pastiprināti pētìt drošību tās daudzveidībā, jo sarunu

6 Jundzis, T. (1995). Latvijas drošība un aizsardzība. Rīga: Junda; Lejiņš, A. (1995). The Baltic Security Dilemma: How to Secure Independence. In: Berry, Ch. (Ed.) The Search for Peace in Europe. Institute for National Strategic Studies and the George C. Marshall European Center for Strategic Studies, Garmisch-Partenkirchen; Lejinšs, A., Apinis, P. (Ed.) (1995). The Baltic States on Their Way to the European Union/Security Aspects. Riga: Latvian Institute of Foreign Affairs; Jundzis, T. (1996). Defence Models and Strategies in the Baltic States. The International Spectator, 31(1), pp. 25-37, DOI: 10.1080/03932729608456728

7 Ozoliņš, A. (1996). Estonia, Latvia and Lithuania in the European Security Architecture: Limits and Opportunities. Lejiņš, A., Bleiere, D. (1996). The Baltic States: Search for Security. Riga: LIA, pp. 76-93; Lejinš, A. (1999). Baltic Security Prospects at the Turns of the 21st Century. Helsinki: Kikimora Publications; Bleijere, D. et al. (1999). The Impact of European Integration Processes on Baltic Security. NATO Fellowship Programme; Lejiņš, A. (red.) (2003). NATO un Eiropas Savienības sadarbība drošîbas jomā: atšķirīgi viedokḷi un kopēji risinājumi. Rīga: Latvijas Ārpolitikas institūts.

8 Lejin̄š, A., Bleiere, D. (1996). The Baltic States: Search for Security. Rīga: LIA; Ozoliṇa, Ž. (2000). Latvijas drošîbas politikas reǵionālie aspekti. Rịga: Izglìtiba; Arteus, G., Lejiņš, A. (1997). The Baltic Security. Looking towards the 21st Century. Stockholm: Forsvarhogskolan / Riga: Latvian Institute of International Affairs.

9 Stranga, A. (1996). Russia and security of the Baltic States 1991-1996. In: Lejiņš, A., Bleiere, D. (eds.) The Baltic States: Search for Security. Riga: LIA, pp. 141-185; Stranga, A. (1997). Baltic Russian relations: 1995 - beginning of 1997. In: Lejin̦š, A., Ozolin̦a, Ž. (eds.) Small States in Turbulent Environement: The Baltic Perspective. Rīga: LIA, pp. 184-238; Ozoliṇa, Ž. (1998). Latvia. In: Mouritzen, H. (ed.) Bordering Russia. Theory and Prospects for Europe's Baltic Rim. London: Ashgate, pp. 131-164; Bleiere, D., Stranga, A. (2000). The Latvian Russian Crisis of 1998. In: Stern, K. E., Hansen, D. (eds.) Crisis Management in a Transitional Society: The Latvian Experience. Stockholm: Försvagshögskolan, pp. 216-259. 
vešana ar ES un NATO notika ne tikai par militārām vai iekšlietu sistēmas spējām, bet par visu drošǐbas politikas spektru.

Sākot ar 2000.-2002. gadu, pieaug pētijumu skaits "visaptverošās drošības" laukā, pievēršoties cilvēkdrošības, ${ }^{10}$ sabiedrības drošības, ${ }^{11}$ ekonomikas drošības un citiem drošības sektoriem. Vēl jo vairāk šo pētijumu paplašināšanas tendenci ietekmēja globālās finanšu un tai sekojošā ekonomikas krīze pasaulē un Latvijā, kas skāra gandrīz ikvienu mājsaimniecību valstī, mazinot tās drošumspēju. Taču nebūtu korekti apgalvot, ka drošības pētījumi koncentrējās tikai uz iekšpolitiskās situācijas apzināšanu. Šajā pašā laikā sākās diskusijas Eiropas Savienībā par tās lielāku lomu pasaules politikā un Kopējās ārējās un drošības politikas (KĀDP) aktīvāku lietošanu. Rezultātā ES, gatavojot jauno Lisabonas līgumu, ${ }^{12}$ kuru pieṇēma 2009. gadā, liela dalïbvalstu uzmanība tika vērsta šis politikas virzienā, kas vienlaicīgi veicināja pētnieku kopienas darbību, apzinot ES potenciālu un vājos posmus. Tādējādi arī Latvijā drošîbas pētỉjumos uzmanība pievērsta ES starptautiskās darbības izvērtējumam. ${ }^{13}$ Īpašu vietu ieṇem analīze par Krieviju kā ES kaimiņvalsti.

Būtisks pavērsiens drošības pētniecībā Latvijā sākas pēc 2014. gada notikumiem Ukrainā, kuri liecina par to valstu pārākumu konfliktu situācijās, kuras spēj savienot militāros ar nemilitāriem līdzekḷiem un kuras mērḳtiecīgi lieto hibrīddraudus savu ieceru sasniegšanai. Militārais konflikts Ukrainā un Krimas teritorijas aneksija būtiski ietekmēja drošības jēdziena izpētes virzienu, kurā vienlīdz svarīgas ir "cietās" un "maigās" drošỉbas komponentes un kurā vienlīdz nozīmīgi ir pētỉjumi par valstu aizsardzības doktrīnām un militārajām spējām, kā arī par sabiedrības, kopienu un indivīdu spēju piemēroties jauniem apstākḷiem, būt noturīgiem pret hibrīddraudu radītajiem izaicinājumiem

10 Skatīt, piemēram, Tautas attīstības pārskats. Cilvēkdrošība. Latvija. (2003). Rīga: UNDP; Ozoliṇa, Ž. (Ed.) (2010). Rethinking Security. Rīga: Zinātne; Ozoliṇa, Ž. (red.) (2012). Cilvēkdrošǐba Latvijā un pasaulē: no idejas lìdz praksei. Rīga: Zinātne; Ozolina, Ž. (Ed.) (2015). Gender and Human Security. A view from the Baltic Sea Region. Rīga: Zinātne.

11 Ozolin̦a, Ž. (Ed.) (2016). Societal Security. Inclusion-Exclusion Dilemma. A Portrait of the Russian Speaking Community in Latvia. Rīga: Zinātne; Aatola, M. et al. (2018). Societal Security in the Baltic Sea Region. Riga: Latvian Institute of Foreign Affairs.

12 Lisabonas līgums. Pieejams: mfa.gov.lv

13 Auers, D., Bukovskis, K. (2006). Eiropas Parlaments un Eiropas kopējā ārējā un drošības politika. No: Ozoliṇa, Ž. (red.) Eiropas Parlaments: ārējās un drošîbas politikas ìstenotājs. Rīga: Zinātne, 15.-40. lpp.; Ozoliņa, Ž., Rostoks, T. (2006). Latvian Outlook on the European Union Common Foreign and Security Policy. In: Tiirma-Klaar, H., Marques, T. (eds.) Global and Regional Security Challenges: A Baltic Outlook. Tallinn: Tallinn University Press; Lejin̦š, A. (red.) (2007). Pastiprināta Eiropas Savienības austrumu kaimiņu politika: jautājumi un izaicinājumi. Rīga: Latvijas Ārpolitikas institūts; Bungs, Dz. et al. (2007). Eiropas Savienības Kopējā ārējā un drošîbas politika vērtību un interešu krustugunīs (bet ne krustcelēs). No: Ozoliṇa, Ž. (red.) Latvijas skatījums uz Eiropas Savienības nākotni. Rīga: Zinātne, 214.-262. lpp.; Ozoliṇa, Ž. (2007). European Security and Defence Policy: the Latvian perspective. In: Archer, Cl. (ed.) New Security Issues in Northern Europe. The Nordic and Baltic states and the ESDP. London: Routledge, pp. 115-138. 
un par līdzatbildību valsts drošỉbas uzturēšanā. ${ }^{14}$ Jēdzieni, kuri šobrīd tiek izmantoti drošības politikā, kā, piemēram, izturētspēja/noturīgums (resilience), ir sinonīmi jau 2003. gadā publicētajam tautas attīstības pārskatā par cilvēkdrošību lietotajam drošumspējas jēdzienam. ${ }^{15}$ Savukārt vairākos pētījumos liktais uzsvars uz nepieciešamību iesaistìt sabiedrību drošības un aizsardzības politikas veidošanā ir vainagojies ar Latvijas valdības akceptēto informatīvo ziņojumu "Par visaptverošas valsts aizsardzības sistēmas ieviešanu Latvijā"16.

90. gadu sākumā bija vērojama atšķirība drošības definējumā, kuru izmantoja Rietumu tradīcijā sakņoti starptautiskās politikas eksperti un Latvijas pētnieki, bet ap 2000. gadu šìs atšķirības samazinājās, lielāku uzmanību pievēršot daudzpusējam šì fenomena skatījumam. Savukārt pēc 2014. gada vienprātība par konvencionālo un hibrīdo apdraudējumu drošības interpretējumā ir tikai pieaugusi.

Diez vai šobrīd atgriešanās pie aukstā kara mēginājumiem paplašināt drošìbas jēdziena interpretāciju vairs ir nepieciešama, jo situācija pēc aukstā kara ir pierādījusi, ka domāšana "vai - vai" kategorijās ir vairāk izdevīga un piemērota akadēmiskām diskusijām, kamēr drošỉbas politika ir spiesta vienlaicīgi risināt šaurās (politiskās un militārās) un paplašinātās (sabiedrības, vides, energêetikas, ekonomikas) drošības jautājumus, ko nosaka pieaugošais apdraudējuma daudzveidīgums un cilvēku pieprasijums pēc atbilstošām politikām. Diskusija par šauro un plašo drošǐbas interpretējumu ir savā ziṇā kḷuvusi bezjēdzīga. Minēto draudu daudzveidības pieauguma dẹl aktuālāks ir jautājums par drošîbas politikas veidotāju un drošības patērētāju spēju - abām pusēm saskatīt draudus, abām pusēm sadarboties to novēršanā, abām pusēm būt spējīgām lietot atbilstošākos līdzekḷus draudu izcelšanās novēršanai un pieaugošas intensitātes apstākḷ̆os to mazināšanai. Šāda mijiedarbỉba var izrādīties visai sarežǧìta, jo nedz valdība ar definēto drošỉbas un aizsardzības politiku, nedz

14 Kudors, A. (red.) (2014). Krievijas publiskā diplomātija Latvijā: mediji un nevalstiskais sektors. Rīga: LU Akadēmiskais apgāds; Internet trolling as a hybrid warfare tool: the case of Latvia. (2016). Riga: NATO Strategic Communications Centre of Excellence; Redefining Euro-Atlantic values and Russia's strategic communication in the Euro-Atlantic space. (2016). Riga: NATO Strategic Communications Centre of Excellence; StratCom Laughs: In search of an analytical framework. (2017). Riga: NATO Strategic Communications Centre of Excellence; Rostoks, T., Vanaga, N. (eds.) (2019). Deterring Russia in Europe. Defence Strategies for Neighbouring States. London: Routledge; Bērzin̦a, I. (red.) (2016). Sabiedrības destabilizācijas iespējamība Latvijā: potenciālie nacionālās drošības apdraudējumi. Rīga: Latvijas Nacionālā aizsardzības akadēmija; Bērziṇa, I. (2020). From 'total' to 'comprehensive' national defence: the development of the concept in Europe. Journal of Baltic Security, 6(2), pp. 1-9; Bērziña, I., Zupa, U. (2020). Latvijas sabiedrības griba aizstāvēt valsti: veicinošie un kavējošie faktori. Rīga: Latvijas Nacionālā aizsardzības akadēmija.

15 Tautas attīstības pārskats. Cilvēkdrošîba. Latvija. (2003). Rīga: UNDP.

16 Latvijas Aizsardzības ministrija. Par visaptverošas valsts aizsardzības sistēmas ieviešanu Latvijā. (2019). Pieejams: Informativais zinojums_VVA ieviesana_2018.pdf (mod.gov.lv) 
indivīdi un sabiedrība ir konstantas vienības. Tās atrodas pastāvīgā mainībā, kas atbilstoši var pārdefinēt, adaptēt vai radìt jaunas izpratnes par apdraudējumu un atbilstošām politiku izvēlēm. Viens no redzamākajiem drošības pētniekiem Bils Maksvīnijs (Bill McSweeney) norādīja, ka drošības politikas nevajadzētu formulēt kā vienkāršu indivīdu vajadzību apkopošanu un to pierakstîšanu valstij, bet uz tām jāskatās kā uz procesu, kurš dinamiski attīstās un kurā sociālie aǵenti, meklējot jaunas identitātes un intereses, rada un piedāvā drošības risinājumus. Šo procesu viņš nosauc par "sociālās kārtības refleksīvo teoriju", piešķirot drošības radītāja statusu indivīdiem un kopienām. ${ }^{17}$ Tieši minētā Maksvīnija atziṇa ir būtiski iespaidojusi grāmatā atspoguḷotā pētijuma gaitu, kas padara tālāk atspoguḷotos rezultātus unikālus un inovatīvus, jo fokusa grupu interviju apkopotie rezultāti ir samēroti ar attiecīgo pašvaldỉbu darbinieku/vadītāju aptaujās iegūto skatījumu par drošības situāciju kopienā. Viens no pētijjumu soḷiem bija noskaidrot, vai pašvaldību darbinieki kā drošības radītāji un labas pārvaldības nodrošinātāji ir informēti par kopienā pastāvošajām bažām un vai viņiem ir sasaiste ar drošỉbas politikas dinamiskajām norisēm nacionālā līmenī.

Šajā pètījumā izmantotais definējums arī pieder pie minētā dominējošà strāvojuma. Tas balstīts pieņēmumā, ka "drošîba ir stāvoklis bez draudiem, .. kā arī valstu un sabiedrības spēja saglabāt neatkarīgu identitāti un to funkcionālu vienotību"18. Berija Buzana (Barry Buzan) piedāvātā definīcija akcentē sabiedrības līdzdalību drošîbas politikas veidošanā, kas ir būtiska subjektīvās uztveres analīzē, kā arī uzsver identitātes un valsts un sabiedrības funkcionēšanu, kuras ir īpaši nozīmīgas hibrīddraudu dominēšanas apstākḷos.

\section{Drošības subjektīvā uztvere}

Neraugoties uz pieaugošu interesi par daudzveidīgu drošîbas aspektu izpēti pēdējo gadu laikā, tomēr ir vairāki aspekti, kuriem nav pievērsta pienācīga uzmanība, bet kuriem ir īpaša nozīme situācijās, kad valstis un sabiedrības var kḷūt par hibrīduzbrukuma objektiem un kad nepietiek ar militāro spēju klātbūtni un efektivitāti, bet nacionālās drošỉbas stiprināšanā un pat aizsardzībā indivīds, grupas un sabiedrība kopumā sadarbojas ar bruṇotajiem spēkiem. Koordinēta visu iesaistīto dalïbnieku rīcība iespējama ar nosacìjumu, ka indivīds

17 McSweeney, B. (1999). Security, Identity and Interests. Sociology of International Relations. Cambridge: Cambridge University Press.

18 Buzan, B. (1991). People, States and Fear. An Agenda for International Security Studies in the PostCold War Era. London: Harvester Wheatsheaf, pp. 18-19. 
vai grupas gūst apstiprinājumu tam, ka viņu subjektīvais drošības redzējums atbalsojas valsts līmeņa prioritāro risku un apdraudējumu sarakstā un valdības rīcỉbpolitikās. Tādējādi veidojas attiecības starp drošǐbas politikas veidotājiem un šĩs politikas patērētājiem, kuri, redzot savu bažu un baiḷu atspogulojumu valsts īstenotajās darbībās, kḷūst par tās līdzīstenotājiem.

Tādēḷ projekta izstrādes gaitā uzmanība pievērsta drošības subjektīvajam uztveres definējumam. Drošỉbas objektīvos un subjektīvos aspektus vēl aukstā kara posmā akcentējis Arnolda Volfers (Arnold Wolfer), rakstot, ka "Drošỉba tās objektīvā nozīmē tiek mērīta ar apdraudējuma trūkumu pastāvošajām vērtībām, subjektīvā drošỉba ar baiļu neesamību, ka šādām vērtībām tiks uzbrukts"19. Drošības uztveri visbiežāk pēta no kvantitatīvā aspekta, noskaidrojot, kādus apdraudējumus dažādas sabiedrības grupas identificē kā prioritārus. Ja pieņem to, ka cilvēki savā apziņā konstruē realitāti tā, lai tā atbilstu pieṇēmumam, kādai tai jābūt vai vajadzētu būt, tad apdraudējumi parāda, cik atšķirīgi un daudzveidīgi ir iedzīvotāju pieṇēmumi par drošību un cik lielā mērā apdraudējumi tiek identificēti un saistìti ar konkrēto kontekstu. Retāk uzmanība pievērsta iemesliem, kāpēc tieši vieni vai otri draudi tiek prioritizēti un kā šis subjektīvais skatījums atspoguḷojas attiecīgās valsts drošības politikā. Draudu identifikācijā un prioritizācijā svarīga ir gan sociālā pieredze, gan sociālā atmiņa. Ārkārtas situāciju vadībā tiek lietots jēdziens "sociālā ievainojamība", kas apzīmē to kontekstuālo faktoru kopumu (piemēram, politisko, sociālo, kultūras), kas iezīmē kādas kopienas lielāku "uzṇēmību" vai reakciju uz draudiem, kamēr citas kopienas, saskaroties ar šiem pašiem draudiem, reaǵe citādāk. ${ }^{20}$

Bobijs Dafijs (Bobby Duffy) norāda, ka ir maz tādu subjektīvās uztveres pētījumu, kas pievēršas maldīgas uztveres skaidrojumiem. Viṇš to skaidro ar nepietiekamiem empīriskiem pierādījumiem. Sabiedriskās domas aptaujas par sociālās realitātes uztveri ir sāktas tikai salīdzinoši nesen - pagājušā gadsimta vidū, un arī pēc tam sekojis tikai salīdzinoši neliels to skaits. ${ }^{21}$

Tikai pēdējos gados piedzìvots šādu pētījumu pieaugums, ${ }^{22}$ ko veicinājusi tehnolog̣iju attīstība, sociālo mediju izplatība un drošîbas elementu klātbūtne

$$
\text { Books, pp. 7-8. }
$$

22 Skatit: Escriba-Folch, A. (2013). Repression, Political Threats, and Survival under Autocracy. International Political Science Review, 34(5), pp. 543-560; Farnham, B. (2003). The Theory of Democratic Peace and Threat Perception. International Studies Quarterly, 47(3), pp. 393-415; Rousseau, D., Garcia-Retamero, R. (2007). Identity, Power, and Threat Perception: A Cross-National Experimental Study. Journal of Conflict Resolution, 51(5), pp. 744-771; Siegrist, M., Gustcher, H., Earle, T. C. (2005). Perception of Risk: The Influence of General Trust, and General Confidence. Journal of Risk Research, 8(2), pp. 145-156; Stein, J. G. (2013). Threat Perception in International 
visās politikās. Kā vienu no šādiem inovatīviem pètījumiem jāmin lietuviešu zinātnieku veikums, lai noskaidrotu vēsturiskās atmiņas ietekmi uz militāro draudu uztveri Lietuvā pagātnē, tagadnē un nākotnē. ${ }^{23}$ Autori secina, ka sabiedrības uzticēšanās institūcijām ietekmē arī indivīdu savstarpējo uzticēšanos, kam ir īpaši liela nozīme apdraudējumu situācijās. Savukārt drošība par nākotni veicina personisko drošumspēju un pārliecību par savu spēju rīkoties. Pandēmijas apstākḷ̆os pieaugošā neapmierinātība un pat dusmas var būt draudu un risku nenovērtēšanas un uz riskiem vērstas uzvedības (piemēram, nepaḳ̣aušanās mājsēdes noteikumiem, sejas aizsargmasku nevalkāšanas u. c.) cēlonis. ${ }^{24}$

Drošības subjektīvā uztvere ne tikai palīdz labāk izprast iedzivotāju skatỉjumu uz apdraudējumiem, kas var atškịirties no valsts rīcibpolitikās definētajiem, bet arī veidot drošỉbas un aizsardzỉbas politiku, kas atspoguḷo sinerğiju starp objektīvi pastāvošajiem izaicinājumiem, par kuriem indivīdi dažādu apsvērumu dēl var nebūt informēti, un vienlaicīgi iekḷauj rīcības, kuras reageè uz iedzīvotāju pastāvošajām bažām. Šādas sinerǵijas pastāvēšana ir nosacijums cilvēku attieksmes un arī uzvedības maiņai, kas palielina iedzīvotāju spēju sevi pasargāt. Uz šādu secinājumu norāda arī Rafaels Prjeto Kurjels (Rafael Prieto Curiel) un Stīvens Ričards Bišops (Steven Richard Bishop), kuri, pētot drošības un viktimizācijas attiecības, secina, ka "Drošǐbas vai nedrošības uztvere var radìt cilvēkos nepieciešamību mainīt savu uzvedību"25.

Arī šie autori norāda uz politikas veidotāju un sabiedrības grupu draudu uztveres interpretācijas savietojamību, kas novērš uztveres un maldīgas uztveres (misperception) iespējamās negatīvās sekas. Viens no pirmajiem par šiem jautājumiem starptautiskās politikas disciplīnā rakstīja Roberts Džerviss (Robert Jervis), uzsverot, ka valstis un politikas veidotāji nereti piel̦auj kḷūdas lēmumu pieņemšanā, jo aplami kalkulē oponenta nolūkus un iespējamās rīcības. Viņš raksta: ja deg māja, tas nenozīmē, ka visi skries uz izeju identisku motīvu vadīti. ${ }^{26}$ Lai arī Džerviss galvenokārt analizē valstu un lēmumu pieñēmēju savstarpèjās uztveres īpatnības, daudzas atziņas iespējams ekstrapolēt uz indivīdu un grupu rīcību. Tà minētais piemērs par ugunsgrēku ir izmantojams,

Relations. In: Huddy, L., Sear, D. O., Levy, J. S. (eds.) The Oxford Handbook Political Psychology. Oxford: Oxford University Press, pp. 364-394.

23 Lašas, A., Matonite, I., Jankauskaite, M. (2020). Facing past, present and future: the role of historical beliefs and experiences in the Lithuanian public perception of military threats. Journal of Baltic studies, 51(2), pp. 199-222.

24 Ibid., pp. 204-207.

25 Curiel, R. P., Bishop, St. R. (2016). A metric of the diference between perception of security and victimisation rates. Crime Science, 5(12), p. 1.

26 Jervis, R. (1976). Perception and Misperception in International Politics. Princeton, New Jersey: Princeton University Press, p. 19. 
skaidrojot Latvijas iedzīvotāju dažādo subjektīvo attieksmi pret valsts dalību NATO, kuru kopumā atbalsta vairākums iedzīvotāju, bet militāro bāzu klātbūtni savās kopienās interpretē atšķirīgi (skatīt Valda Otzuḷa rakstu grāmatā). Atgādinājums, ka spēlētājs A spriež par spēètāju B, balstoties uz tā sūtītajiem signāliem, var izrādīties maldīgas uztveres rezultāts. Lai izprastu B iespējamās rīcības, jānoskaidro tā tradīcijas, nacionālais stils, iekšējie konflikti, viṇa paša izkalkulētās potenciālās rīcības sekas. ${ }^{27}$

Latvijas iedzīvotāju subjektīvās drošības uztveres metodoloǵiskā ietvara konstruēšanai svarīgi ir divi koncepti, kuri l̦auj pievērst uzmanību indivīdu un grupu lomai. Tas ir cilvēkdrošības un sabiedrības drošỉbas jēdziens. Cilvēkdrošības koncepcijā uzmanība pievērsta katra indivīda pamatvajadzību nodrošināšanai, kas tiek raksturota kā "brīvība no bailēm un brīvība no trūkuma"28. Pie tam šajā konceptā tiek izšķirti tādi drošības sektori, kuri parasti trūkst tradicionālajās drošỉbas studijās. Tie ir: veselības drošība, ekonomiskā, personiskā, ekolog̣iskā, kopienas, politiskā drošība un uzturdrošība. Šie ir tieši tie drošības aspekti, kuri aktualizējas krīzes apstākḷ̆os un demonstrē valdības spēju veidot iekḷaujošu un ilgtermiṇa drošibas politiku, kas rada priekšnoteikumus institūciju un indivīdu savstarpējai uzticíbai. Tādēḷ arī šajā pētījumā ir izmantoti minētie drošỉbas sektori, papildinot tos ar militāro un hibrīddraudu sektoru.

Savukārt sabiedrības drošības jēdziens raksturo grupu un visas sabiedrības spēju izturēt un saglabāt savu patību pastāvīgi mainīgos apstākḷos vai apdraudējuma situācijās, kā arī tādu savu tradicionālu modeḷu kā valoda, kultūra, reliǵija un nacionālā identitāte ilgtspēju..$^{29}$ N̦emot vērā 21. gadsimta izaicinājumus, kas saistīti ar tādiem tradicionāliem (cietās drošîbas / šaurā interpretējuma) apdraudējumiem cilvēka un grupu eksistencei kā robežu pārskatī̌̌ana, teritoriju okupēšana, vardarbīgu konfliktu izraisīšana, terorisms, kā arī iepriekš nepieredzēti un masveida raksturu ieguvušie riski, kas izriet no pandēmijas, hibrīddraudu, klimata pārmaiņu, nekontrolētas migrācijas un citiem apdraudējumiem, gan valstis, gan sabiedrïbas, gan indivīdi ir vienlïdz pakḷauti eksistenciālām bailēm un satraukti par identitātes saglabāšanu. Pastāvošo dažādo draudu kombinācijas vēl jo vairāk rada nosacījumus un arī nepieciešamību apzināt objektīvu pastāvošo un subjektīvo drošỉbas uztveri, kas padara indivīdus un grupas par drošības politikas līdzdarbīgām vienībām. Princeton University Press, pp. 21-22.

28 Human Development Report 1994. Oxford: Oxford University Press, pp. 22-24.

29 Buzan, B. et al. (1993). The European Security Order Recast. Scenarios for the Post-Cold War Era. London, New York: Pinter Publisher, p. 4. 
Sabiedrības drošìba ir nozīmīgs nacionālās un starptautiskās drošības nosacijjums, jo tas raksturo attiecības starp dažādām sabiedrībā pastāvošām grupām, kurām ir raksturīgas miermīlīgas un uz savstarpēju sadarbỉbu balstītas attiecibas, kas vairo stabilitāti, savukārt spriedze vai pat konflikti ir nestabilitātes avots un negatīvi ietekmē starptautisko vidi. Attiecības starp grupām, kuras sakṇotas subjektīvā drošìbas uztverē, jo tās skar identitātes aspektus, var būtiski iespaidot grupu uzvedību. Jo īpaši tam ir nozīme, ja pieaug dažādu grupu atšķirības - diskriminācija, favorītisms grupās, vienas grupas pārākums pār citu grupu, tas vairo spriedzi. Drošības subjektīvo aspektu analīzē ir svarīga sevis, savas grupas (in-group) un citas grupas (out-group) savstarpējā uztvere, ${ }^{30}$ kā arī pastāvošo atš̌kirību raksturs (naidīgs-draudzịgs-neitrāls). Ja starp grupām pastāvošās atškiriības subjektīivi netiek uztvertas kā apdraudošas, tad ir lielākas iespējas ilgstošai stabilitātei. Savukārt, ja pastāvošās atšķirības pārvēršas apdraudējumā, tad sabiedrība kḷūst par risku avotu, kas sarežğì nacionālās drošības mērḳu sasniegšanu.

Zinātniskās literatūras klāstā atrodami pētījumi par faktoriem, kas ietekmē subjektīvo uztveri. Tā jau pieminētie Kurjels un Bišops izšķir faktorus, kas ietekmē noziedzības uztveres līmeni. Tas var noderēt arī plašākā draudu analīzē. Piemēram, viens no tiem ir iepriekšèjā pieredze saskarsmē ar attiecīgo draudu; starptautiskā, nacionālā un lokālā vide, kura veicina vai samazina attiecīga drauda pastāvēšanu un izplatību; grupas, pie kuras pieder indivīds, pieredze un piedāvātie risinājumi; mediji un sociālie mediji draudu atspoguļošanā var situāciju saasināt un ietekmēt gan uztveri, gan uzvedību. ${ }^{31}$ Iepriekšèja saskare ar draudu var palielināt bailı sajūtu. Pēc terorisma uzbrukumiem 2001. gada 11. septembrī sabiedriskās domas aptaujas ASV tūlīt demonstrēja, cik lielas bailes amerikāṇu sabiedrības pārstāvji bija pārdzìvojuši. Tās emocionālā reakcija krietni pārsniedza reālos riskus. Saskaṇā ar Hārvarda Universitātes profesores Dženiferas Lerneres (Jeniffer Lerner) sniegto informāciju intervijā pēc 11. septembra teroraktiem, 30\% aptaujāto piel̦āva iespējamību, ka viṇi varētu kḷūt par teroristu upuriem tuvākajos 12 mēnešos. ${ }^{32}$

Pie līdzīgiem secinājumiem nonākuši Daniels Stīvens (Daniel Stevens) un Niks Vons-Viljams (Nick Vaughan-Wiljams). Viṇi apgalvo, ka vide vai tiešāk konteksts, kurā persona ir sastapusies ar draudiem, nosaka, vai nākamo reizi

30 Hogg, M., Abrams, D. (1988). Social Identifications: A Social Psychology of Intergroup Relations and Group Processes. London: Routledge, p. 23.

31 Curiel, R. P., Bishop, St. R. (2016). A metric of the diference between perception of security and victimisation rates. Crime Science, 5(12), pp. 1-2.

32 Vedantam, S. How Emotional Responses To Terrorism Shape Attitudes Toward Policies. 22.12.2015. Radio NPR. Pieejams: https:/www.npr.org/2015/12/22/460656763/how-emotional-responses-toterrorism-shape-attitudes-toward-policies 
situācija tiks uztverta kā draudīga vai ne. Tā, piemēram, imigrācijas draudi vai vides piesārņojums vistiešākā veidā tiek saistīts ar kontekstu un sociālo pieredzi, kur, trūkstot sociālajai pieredzei, faktors (piem., vides piesārņojums) var nelikties tik draudīgs vai, gluži pretēji, var kḷūt draudīgs, ja persona šo faktoru "ieliek" sev zināmā kontekstā, kā, piemēram, piesārṇojums tuvu manai mājai. ${ }^{33}$ Arī noziedzības gadījumā indivīds var uztvert savu tiešo vidi kā nedrošu, bet tajā paša laikā nebaidīties, ka viņš varētu kḷūt par upuri, vai arī nebaidīties tāpēc, ka viņš ir veicis pasākumus, lai nekḷūtu par upuri. ${ }^{34}$

Vēl viena psihologiska reakcija, kas var ietekmēt subjektīvo uztveri, ir dusmas. Lernere norāda, ka uz traǵiskiem un šķietami lieliem apdraudējumiem, kā, piemēram, terorisma uzbrukums, sievietes biežāk reagè ar bailēm, bet vīrieši ar dusmām. Dusmas mazina riska izjūtu. Cilvēkiem, kas izjūt šīs emocijas, retāk sajūtas kā upuri. Turklāt tie ir gatavi paši uzṇemties papildu riskus, pateicoties iespējamai vēlmei rīkoties agresīvi, un var veidoties vienkāršošanās mehānismi. ${ }^{35}$ Zìmīgi, ka citi pētỉjumi ASV pierāda, ka ziņas par ekonomiskiem draudiem iedzīvotājos drīzāk izraisa dusmas, nevis bailes. Tādējādi ar emociju starpniecību indivīdi nosaka to, kāda nozīme tiek piešķirta tam vai citam draudu veidam. ${ }^{36}$

Šis atziņas daḷēji sakrīt ar Dafija aprakstītajām draudu uztveres īpatnībām. Viņš norāda, ka attiecībā uz noziedzības uztveri pētījumi daudzu valstu sabiedrībās pierāda, ka neatkarīgi no tā, vai patiesais noziedzības un vardarbïbas līmenis krīt vai ne, kopējais apdraudējuma sajūtas līmenis tomēr saglabājas. Turklāt to nav iespējams tieši saistīt tikai un vienīgi ar noziedzības atainojuma intensitāti medijos, kas vienmēr būs salīdzinoši augsta. Dafijs savos un kolēgu pètījumos to galvenokārt saistījis ar indivīdu uztveres un "maldīgās" uztveres ipatnībām, kas piemīt ikvienam indivīdam. To ilgtermiņā ietekmē dažāda rakstura negatīvas informācijas lielais apjoms publiskajā telpā, kā arī ieradums dot priekšroku tieši šāda veida informācijai. Politiķu un pazīstamu cilvēku radītas dramatiskas ainas un runas sabiedrībai šķiet interesantākas un pievilcīgākas. Rezultātā neatkarīgi no objektīvās realitātes, piemēram,

33 Stevens, D., Vaughan-Williams, N. (2014). Citizens and Security Threats: Issues, Perceptions and Consequences Beyond the National Frame. British Journal of Political Science, 46, pp. 149-175, DOI: 10.1017/S0007123414000143

34 Curiel, R. P., Bishop, St. R. (2016). A metric of the diference between perception of security and victimisation rates. Crime Science, 5(12), p. 2.

35 Vedantam, S. How Emotional Responses To Terrorism Shape Attitudes Toward Policies. 22.12.2015. Radio NPR. Pieejams: https://www.npr.org/2015/12/22/460656763/how-emotional-responses-to-terrorism-shape-attitudes-toward-policies

36 Coan, Travis G. et al. Emotional Responses to Human Security Threats: Evidence from a National Experiment. 31.10.2012. Pieejams: www.travisgcoan.com/replication-materials.html. 
fakta, ka kopumā kriminogēnā situācija vēsturiski kḷūst arvien labāka, mums piemìt tendence domāt pretēji, secina Dafijs. ${ }^{37}$

Situācijās, kad indivīds ilgstoši pārdzīvo spēcīgas bažas, tam rodas nopietnas grūtîbas novērst savu uzmanību uz kaut ko citu, ${ }^{38}$ kā arī potenciāli var rasties citi kognitīvās kontroles traucējumi, piemēram, uztverot informāciju par iespējamo apdraudējumu. ${ }^{39}$ "Draudi mūsu smadzenēs kḷūst arvien lielāki un lielāki, ${ }^{\prime 40}$ raksta Dafijs. Cita pētnieku grupa - Leonijas Hadijas (Leonie Huddy) vadībā - norāda, ka, pieaugot apdraudējuma sajūtai, samazinās politiskā tolerance, pieaug aizspriedumi un etnocentrisms, ${ }^{41}$ kas var novest pie drošíbas situācijas pasliktināšanās.

Paralēli iedzīvotāju subjektīvajai draudu uztverei svarīgi aplūkot arī draudu intensitāti un to prioritāro uztveri. Nosacīti sadalot draudus divās grupās - personīgajos un sociotropiskajos draudos -, vērojama savdabīga aina. Hadija $^{42}$ norāda, ka nacionāla līmeņa draudi visbiežāk atspoguḷojas cilvēku uztverē saistībā ar ekonomiskajām sekām, kamēr personīgā līmeņa draudi veicina personīgo paradumu maiņu, lai mazinātu potenciālos draudus. No uztveres perspektīvas sociotropiskie draudi tiek uztverti kā tālāki no indivīda ikdienas gaitām, tomēr pētījumi parāda, ka indivīds daudz biežāk savā apziṇā veido konstrukciju "sabiedrības apstākḷi un valdība" nekā konstrukciju "paša apstākḷi un publisko amatpersonu rīcība" ${ }^{\text {”3 }}$. Šāda konstrukcija liecina, ka visbiežāk arī medijos sociotropiskie draudi tiek asociēti ar nacionālo līmeni un mazāka uzmanība pievērsta personiskajiem draudiem.

Šì pētījuma mērḳis ir noskaidrot, vai Latvijas iedzīvotāju subjektīvais skatījums uz apdraudējumiem atbalsojas politikas veidotāju piedāvātajos rīcībpolitiku risinājumos. Tādēḷ no plašajām teorētiskajām atziṇām par drošîbas subjektīvo uztveri empīisko datu ieguvei īpaši svarīgas ir šādas atziṇas: baiḷu līmenis dažādos drošîbas sektoros, kas var rezultēties pasivāa reakcijā uz

37 Duffy, B. (2018). The Perils of Perceptions. Why We're Wrong About Nearly Everything. Atlantic Books, pp. 121-129.

38 De Raedt, R., Koster, E. H. W. (2010). Understanding vulnerability for depression from a cognitive neuroscience perspective: Areappraisal of attentional factors and a new conceptual model. Cognitive, Affective, \& Behavioral Neuroscience, 10, pp. 50-70.

39 Beckwe, M. (ed.) (2013). Worrying and Rumination are Both Associated with Reduced Cognitive Control. Psychological Research, 9, p. 2, DOI: 10.1007/s00426-013-0517-5

40 Duffy, B. (2018). The Perils of Perceptions. Why We're Wrong About Nearly Everything. Atlantic Books, p. 125.

41 Huddy, L. et al. (2002). The Consequences of Terrorism: Disentangling the Effects of Personal and National Threat. Political Psychology, 23(3), p. 486. Pieejams: https://cpb-us-el.wpmucdn.com/ you.stonybrook.edu/dist/f/1052/files/2018/03/Huddy-Feldman-Capelos-and-Provost-2002-TheConsequences-of-Terrorism-rpyn7l.pdf

42 Ibid.

43 Ibid. 
notiekošo un mazināt līdzdalību visaptverošas aizsardzības sistēmas veidošanā; dusmu pastāvēšana sabiedrības grupās, kas savukārt var radīt priekšnoteikumus radikalizācijai un agresijai; pārliecība par nākotnes attīstību kā savas drošumspējas/noturīguma rādītājs; uzticēšanās institūcijām/valdībai, kas veicina sadarbību starp drošības veidotājiem, tai skaitā pašu sabiedrību.

\section{ledzīvotāju subjektīvā drošības uztvere un drošības politikas veidošana: pētījuma rāmējums}

Mūsdienās ikviena rīcībpolitikas veidošana ir saistīta gandrīz ar visa plašā apdraudējuma spektra apzināšanu un ietekmes uz sabiedrību prognozēšanu. Šajā daudzveidīgajā un sarežgìitajā situācijā sabiedrība ir viens no nozīmīgākajiem partneriem eksistējošo un potenciālo draudu novēršanā. Taču šie dažādie draudi un riski sabiedrỉbā tiek atšķirīgi uztverti un prioritizēti. Dạ̦ā indivīdu tie izraisa bailes, citos dusmas, vēl citos neuzticību politikas veidotājiem un to pieṇemtajiem lēmumiem un rīcībpolitikām. Attiecīgi arī sabiedrības pārstāvju drošỉbas izjūtas un labsajūtas nodrošināšana neaprobežojas ar valsts ārējo robežu sargāšanu vai indivīdu fiziskās drošîbas garantēšanu. Drošības politikas veidotājiem līdz ar to jālieto kompleksa pieeja iedzīvotāju drošumspējas veidošanā, kurā vienlīdz liela nozīme ir gan valsts neatkarības nodrošināšanai, gan arī privātumam un datu drošỉbai kibertelpā, sabiedrības veselībai, personiskai drošībai, emocionālai un garīgai labklājỉbai u. c. Lìdz ar to mūsdienās var tikt uzdoti pamata jautājumi, lai uzzinātu, kā sabiedrība formulē stāvokli, kurā jūtas droši; kāda veida draudus mēs uzskatām par primāriem; vai politikas veidotāji apzinās un spēj reagêêt uz sabiedrības pārstāvju vajadzībām.

Lai rastu atbildes uz jautājumiem, vai un kā cilvēku drošîbas uztvere atspoguḷojas drošǐbas politikā, kādus un, galvenais, kāpēc viṇi identificē vienus vai otrus draudu veidus un vai pašvaldỉbas reagee uz cilvēku bailēm/bažām, tās mazinot, vai rodas saikne starp drošîbas politikas veidotāju un patērētāju, izveidota vairāku posmu izpētes darba metodolog̣ija, kas atspoguḷota attēlā.

Pirmkārt, projekta atskaites punkts bija daudzās Latvijā veiktās sabiedriskās domas aptaujas, kuras iezīmē iedzīvotāju attieksmi pret drošîbas situāciju valstī un galvenajiem draudu veidiem. Tas savukārt palīdzēja veidot jautājumus fokusa grupu intervijām šì projekta mērḳu sasniegšanai. Pētījumā izmantoti to Latvijas un starptautisko sabiedriskās domas aptauju rezultāti, kas atainoja Latvijas iedzīvotāju viedokḷus un noskaņojumus, kuri bija apkopoti laika posmā no 2014. gada līdz 2019. gada sākumam. Saskaṇā ar tiem Latvijas iedzīvotāji pamatā kā nozīmīgus saskata draudus, kuru avots ir valstī, nevis 


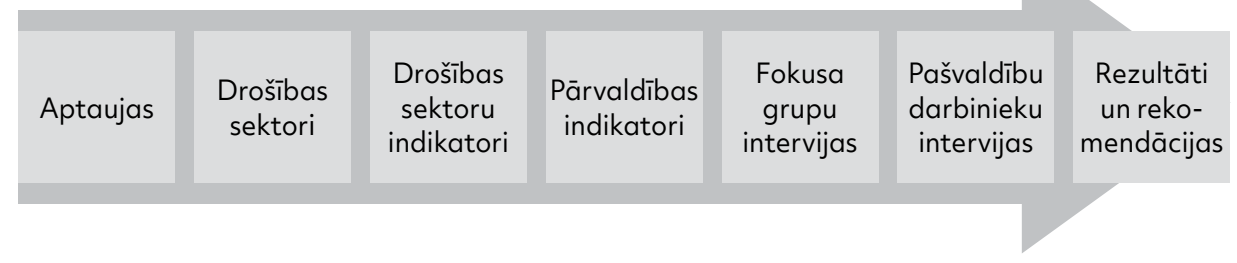

Pētijuma īstenošanas posmi

ārējus draudus. ${ }^{44}$ Starp nozīmīgākajiem apdraudējumiem Latvijas iedzīvotāji identificējuši sociālus draudus, piemēram, zemas algas, bezdarbs, nepietiekamas sociālās garantijas. ${ }^{45}$ Iedzīvotāju neapmierinātība ar valsts pārvaldes darbu, neuzticēšanās politiskajai elitei veicinājusi situāciju, kad vairāk nekā puse Latvijas iedzīvotāju dažādās sabiedriskās domas aptaujās paudusi pilnīgu vai daḷēju neuzticēšanos nacionāla līmeņa valsts pārvaldes iestādēm, galvenokārt valdībai un Saeimai, ${ }^{46}$ un to darbību skatījusi kā iespējamu apdraudējumu. ${ }^{47}$ Līdzās šim bieži atzīmēta arī korupcija kā nozīmīgs apdraudējums. ${ }^{48}$ Aptauju dati norāda uz to, ka Latvijas iedzīvotājus satrauc arī demogrāfiskie jautājumi, piemēram, sabiedrības novecošana, zema dzimstība, ekonomiskā situācija valstî. ${ }^{49}$ Lai arī retāk nekā iepriekšêjās draudu grupas, tomēr aptaujās parādījušies arī tādi iedzīvotāju identificētie draudu veidi kā Latvijas integrācijas problēmas un divkopienu sabiedrības esamība, imigrācija, ekolog̣iskās problēmas un

44 Nacionālā Aizsardzības akadēmija (2016). Sabiedrības destabilizācijas iespējamība Latvijā: potenciālie nacionālās drošības apdraudējumi. Rīga: Nacionālā Aizsardzības akadēmija; SKDS. Latvijas Barometrs, 19.06.2016.; Eurobarometer, Special Eurobarometer 464b. Security, June 2017; Eurobarometer, Autumn 2018; SKDS, 02.2018.; SKDS. Latvijas Barometrs, 10.2018.

45 Nacionālā Aizsardzības akadēmija (2016). Sabiedrības destabilizācijas iespējamība Latvijā: potenciālie nacionālās drošības apdraudējumi. Rīga: Nacionālā Aizsardzības akadēmija; SKDS. Latvijas Barometrs, 06.2016.; Eurobarometer, Autumn 2018; SKDS. Latvijas Barometrs, 10.2018.

46 Salīdzinoši - pašvaldībām iedzīvotāji uzticas ievērojami vairāk. Piemēram, SKDS 2018. gada februārī veiktā aptauja rādīja, ka vairāk nekā puse Latvijas iedzīvotāju ir pilnībā vai daḷēji apmierināti ar savas pašvaldības darbu.

47 SKDS. Latvijas Barometrs, 12.2016.; SKDS, 07.2017.; Pew Research. Ethnic Russians in Some Former Soviet Republics Feel a Close Connetion to Russia. 24.07.2017. Pew Resarch. Pieejams: http://www. pewresearch.org/fact-tank/2017/07/24/ethnic-russians-in-some-former-soviet-republics-feel-aclose-connection-to-russia/; SKDS. Latvijas Barometrs, 10.2017.; SKDS, 02.2018.; SKDS, 07.2018.; SKDS, 11.2018.; Eurobarometer, 09.2018.

48 Nacionālā Aizsardzības akadēmija (2016). Sabiedrības destabilizācijas iespējamība Latvijā: potenciālie nacionālās drošības apdraudējumi. Rīga: Nacionālā Aizsardzības akadēmija; SKDS. Latvijas Barometrs, 12.2016.; SKDS. Latvijas Barometrs, 10.2017.

49 Nacionālā Aizsardzības akadēmija (2015). Aktuālās drošības problēmas Latvijā. Rīga: Nacionālā Aizsardzības akadēmija; SKDS. Latvijas Barometrs, 06.2016.; SKDS. Latvijas Barometrs, 10.2017.; SKDS, 06.2018.; SKDS. Latvijas Barometrs, 12.2018. 
dabas katastrofas, kiberdraudi personiskā un nacionālā līmenīi. ${ }^{50}$ Attiecībā uz iekšējiem draudiem nepastāv ievērojamas atšķirības starp Latvijas iedzīvotāju viedokḷiem atkarībā no to etniskās vai lingvistiskās piederības. Tiesa, krievvalodīgie Latvijas iedzīvotāji biežāk Latvijas valsti skata kā svešu un naidīgu, kā apdraudējuma avotu to personiskajai drošībai. ${ }^{51}$ Kā nozīmīgāko ārējo apdraudējuma avotu Latvijas iedzīvotāji galvenokārt minējuši Krievijas Federācijās ārpolitiku. Un te pastāv ievērojamas atšķirības starp divām lingvistiskās piederības grupām. Latviešu vidū šāda viedokḷa atbalstītāju īpatsvars bija salīdzinoši liels un aptaujās sasniedza vairāk nekā pusi no kopējā aptaujāto skaita, bet starp krievvalodīgajiem respondentiem šāda viedokḷa atbalstītāju skaits aptaujās nesasniedza pat 1/5. Krievijas Federācijas aktivitātes drīzāk viṇi skatījuši kā tādas, kas līdzsvaro Rietumu realizētās politikas un/vai aizstāv krievvalodīgos ārpus tās robežām..$^{52}$ Aptaujās iezīmējās arī Latvijas iedzīvotāju bažas par NATO spēku klātbūtni kā iespējamo to apdraudējuma avotu. ${ }^{53}$

Otrais pētijuma solis bija saistīts ar drošìbas sektoru noteikšanu. Tajos notiktu apdraudējumu identificēšana ar izvēlētu indikatoru palīdzību. Šajā gadījumā autori izmantoja gan Barija Buzana klasisko iedalïjumu ekonomiskajos, politiskajos, militārajos, vides, sabiedrības un strukturālajos sektoros, ${ }^{54}$ gan Apvienoto Nāciju Organizācijas Attīstības programmas ietvarā izstrādātos cilvēkdrošības jēdzienu skaidrojošos sektorus - veselību, personisko, kopienas, vides, politisko. ${ }^{55}$ N̦emot vērā pēdējos gados pieaugošo un Latvijas situācijai īpaši nozīmīgo hibrīdapdraudējumu, tad arī tie iekḷauti kopējā sarakstā. Tieši hibrīddraudi un riski indivīdam un sabiedrībai rada apstākḷus personiskiem kognitīvi emocionāliem konfliktiem, kuriem raksturīgas tādas pazīmes

50 Nacionālā Aizsardzības akadēmija (2016). Sabiedrības destabilizācijas iespējamība Latvijā: potenciālie nacionālās drošîbas apdraudējumi. Rīga: Nacionālā Aizsardzības akadēmija; SKDS. Latvijas Barometrs, 06.2016; Eurobarometer, 11.-12.2016; SKDS. Latvijas Barometrs, 12.2016.; Pew Resarch. Pieejams: http://www.pewresearch.org/fact-tank/2017/07/24/ethnic-russians-in-someformer-soviet-republics-feel-a-close-connection-to-russia/; SKDS. Latvijas Barometrs, 10.2017; SKDS, 11.2017.; SKDS, 04.2018.; SKDS, 05.2018.; Eurobarometer, Autumn 2018; SKDS, 10.2018.; SKDS, 12.2018 .

51 Ozoliņa, Ž. (Ed.) (2016). Societal Security. Inclusion-Exclusion Dilemma. A Portrait of the Russian Speaking Community in Latvia. Rīga: Zinātne.

52 Nacionālā Aizsardzības akadēmija (2016). Sabiedrības destabilizācijas iespējamība Latvijā: potenciālie nacionālās drošîbas apdraudējumi. Rīga: Nacionālā Aizsardzības akadēmija; Pew Research. Ethnic Russians in Some Former Soviet Republics Feel a Close Connetion to Russia. 24.07.2017. Pew Resarch. Pieejams: http://www.pewresearch.org/fact-tank/2017/07/24/ethnic-russiansin-some-former-soviet-republics-feel-a-close-connection-to-russia/

53 Nacionālā Aizsardzības akadēmija (2016). Sabiedrības destabilizācijas iespējamība Latvijā: potenciālie nacionālās drošības apdraudējumi. Rīga: Nacionālā Aizsardzības akadēmija.

54 Buzan, B. (1991). People, States and Fear. An Agenda for International Security Studies in the PostCold War Era. London: Harvester Wheatsheaf, pp. 116-134.

55 Tautas attīstības pārskats. Cilvēkdrošība. Latvija. (2003). Rīga: UNDP, 30. lpp. 
kā apjukums, dezorientācija, motivācijas zaudēšana, depresija, noliegums, saiknes zaudēšana ar realitāti, vājums, bailes vai pārspīlēta kāda apbrīnošana un citas, kas norāda uzbrukuma vektorus potenciālajam ienaidniekam, lai ietekmētu un pakḷautu izvēlēto indivīdu vai grupu sev vēlamā virzienā un veidā. Šādās situācijās cilvēks pats vairs nav savas izvēles noteicējs, bet pakḷaujas citu kontrolei. Jo īpaši šādi kognitīvie konflikti tiek izmantoti "kritiskos laikos" (vēlēšanas, gatavošanās militārām operācijām, sabiedriskās domas atbalsta iegūšanas kampaṇās). ${ }^{56}$

Treškārt, balstoties uz vairākām sabiedriskās domas aptaujām, kas veiktas Latvijā un veltītas iedzīvotāju attieksmes pret drošỉbas situāciju (Latvijā, Eiropā un pasaulē) apkopošanai un cilvēkdrošības pētījumu izvērtēšanai, tika izveidots Latvijai nozimmīgāko drošības sektoru saraksts un atbilstoši tam atlasīti indikatori, kas bijuši lietoti un pārbaudīti iepriekšējos pētījumos. ${ }^{57}$ Drošības sektoru un attiecīgo indikatoru saraksts atspogulots 1. tabulā.

Ceturtais solis bija saistīts ar pārvaldības jēdziena un tādu pārvaldības indikatoru definēšanu un atlasi, kuri būtu piemērojami dažādiem drošības sektoriem. Draudu sekas ir gan politiskās uzvedības maiṇa, gan arī valdības reakcijas un pārvaldības efektivizācija. ${ }^{58}$

Labas pārvaldības jēdziens visbiežāk tiek lietots, lai aprakstìtu procesus politiskajā un administratīvajā sistēmā, kur iesaistās institūcijas un privātie uzņēmēji, indivīdi un nevalstiskās organizācijas, lai panāktu labāku valsts pārvaldes darbību un operatīvāku reakciju uz sabiedrības problēmām un izaicinājumiem. Lai arī mēdz runāt par labo pārvaldību (good governance) un viedo pārvaldību (smart governance), ${ }^{59}$ šajā pētijumā tika izmantotas Pasaules Veselības organizācijas piedāvātie kritēriji viedajai pārvaldība (smart governance), saucot to par labu pārvaldību, jo tieši termins "laba pārvaldība" ir akceptèts Latvijas sabiedrībā.

Sākotnēji labas pārvaldības jēdziens tika saistīts ar piecām pārvaldes vērtībām - atvērtība, līdzdalība, atbildīgums, efektivitāte un saskaņotība, ko

56 Skatīt: Wells II, L. (2017). Cognitive-Emotional Conflict - Adversary Will and Social Resilience. PRISM, 7(2). Pieejams: Cognitive-Emotional Conflict - Adversary Will and Social Resilience > PRISM | National Defense University > News (ndu.edu); Studeman, W. O. (02.2017). Tutorial on Managing the Overlap Between and Alignment of Cyber, Information Warfare/Conflict/Operations and Intelligence (including all forms of security), p. 27.

57 Ozoliṇa, Ž. (red.) (2012). Cilvēkdrošỉba Latvijā un pasaulē: no idejas lìdz praksei. Rīga: Zinātne; Ozolina, Ž. (red.) (2016). Societal Security. Inclusion-Exclusion Dilemma. A Portrait of the Russian Speaking Community in Latvia. Rịga: Zinātne; Nacionālā Aizsardzības akadēmija (2015). Aktuālās drošǐbas problēmas Latvijā. Rīga: Nacionālā Aizsardzības akadēmija un citi.

58 Stevens, D., Vaughan-Williams, N. (2014). Citizens and Security Threats: Issues, Perceptions and Consequences Beyond the National Frame. British Journal of Political Science, 46, pp. 149-175, DOI: $10.1017 /$ S0007123414000143

59 World Health Organization. Governance for health in the 21st century. 2012. 
1. tabula. Drošības sektori

\begin{tabular}{|c|c|}
\hline Drošības sektori & Indikatori \\
\hline $\begin{array}{l}\text { Ekonomikas } \\
\text { sektors }\end{array}$ & $\begin{array}{l}\text { Pirktspēja } \\
\text { Spēja veidot uzkrājumus } \\
\text { lenākumu stabilitāte } \\
\text { Pieeja finansiālam atbalstam nepieciešamības gadījumā } \\
\text { Uzṇēmējdarbības vides stabilitāte un prognozējamība } \\
\text { Ekonomikas noturība pret globālās ekonomikas svārstībām un eksporta } \\
\text { tirgu diversitāte } \\
\text { Administratīvais slogs uzṇēmējdarbībai un uzṇēmējdarbības uzsākšanai }\end{array}$ \\
\hline $\begin{array}{l}\text { Politikas } \\
\text { sektors }\end{array}$ & $\begin{array}{l}\text { Valdības stabilitāte } \\
\text { Pienemto lēmumu leǵitimitāte } \\
\text { Politiskais atbalsts drošības situācijas uzlabošanai valstī } \\
\text { Attiecību raksturs starp nacionālo un lokālo/pašvaldību līmeni } \\
\text { Sabiedrības līdzdalība vēlešanās } \\
\text { Uzticība politiskiem institūtiem }\end{array}$ \\
\hline $\begin{array}{l}\text { Sabiedrības } \\
\text { drošîbas } \\
\text { sektors }\end{array}$ & $\begin{array}{l}\text { Grupu identitāte un tās saglabāšanas iespējas } \\
\text { Izglîtības pieejamība } \\
\text { Sabiedrības līdzdalība } \\
\text { Ticības brīvība } \\
\text { Kultūras daudzveidība } \\
\text { Kopienas pašizpausmes iespējas } \\
\text { Psiholoǵiskais noturīgums }\end{array}$ \\
\hline $\begin{array}{l}\text { Vides } \\
\text { sektors }\end{array}$ & $\begin{array}{l}\text { Apdraudēto resursu aizsargāšana } \\
\text { Rīcībspēja dabas katastrofu radīto seku pārvarēěanā } \\
\text { Likumdošana vides piesārṇojuma mazināšanai } \\
\text { Iniciatīvas klimata pārmainu mazināšanai } \\
\text { Vides resursu kvalitāte }\end{array}$ \\
\hline $\begin{array}{l}\text { Militārais } \\
\text { sektors }\end{array}$ & $\begin{array}{l}\text { Valsts robežu drošība } \\
\text { Spēja nepielaut citas valsts iebrukumu } \\
\text { Spēja aizsargāt valsti iebrukuma gadījumā (bruṇoto spēku gatavība, } \\
\text { spējas, iedzīvotāju griba un gatavība) } \\
\text { Finansiālais nodrošinājums NBS spēju attīstībai } \\
\text { Sabiedrības iesaiste valsts aizsardzībā - dalība Zemessardzē, } \\
\text { jaunsardzē vai iestāšanās profesionālajā dienestā }\end{array}$ \\
\hline $\begin{array}{l}\text { Hibrīddraudu } \\
\text { sektors }\end{array}$ & $\begin{array}{l}\text { Fiziskā drošība un aizsardzība pret dabas katastrofām } \\
\text { Informācijas drošība - viltus zinnas, mediju brīvība, vide un patība } \\
\text { Citu valstu iejaukšanās iekšējās lietās un to ietekme } \\
\text { Kiberuzbrukumi } \\
\text { Kritiskās infrastruktūras apdraudētība }\end{array}$ \\
\hline $\begin{array}{l}\text { Personiskās } \\
\text { drošības sektors }\end{array}$ & $\begin{array}{l}\text { Veselība } \\
\text { Sociālā aizsardzība } \\
\text { Labklājība } \\
\text { Fiziskā drošība } \\
\text { Emocionālā drošība } \\
\text { Noziedzības līmenis }\end{array}$ \\
\hline
\end{tabular}


Eiropas Savienība definēja 2001. gadā. Taču, tā kā valsts pārvaldei un pašvaldībām risināmie jautājumi kḷuva arvien sarežg̀itāki, bija nepieciešama "kopējā risinājuma meklēšanas stratēégija”, kur publiskās pārvaldes iestādes kopā ar sabiedrību un politiķiem konstruktīvi sadarbojas. Taču ne visiem pārvaldības dalïbniekiem ir kopīgas vērtības un, vēl jo vairāk, kopīga izpratne par to, kas ir vērtības un kādām jābūt vērtỉbām, uz kuru bāzes tiek veidota sadarbība, lai risinātu sarežğìtas sociālekonomiskas vai apstākḷu izraisītas ārkārtas situācijas. Tādēl vēlāk pārvaldības definējumi atspoguḷo nosacỉjumus "labākā risinājuma meklēšanas stratēǵija" ${ }^{\prime 60}$, kas ietver virkni nosacijumu. Tā pārvaldības pamatā ir pieṇēmums, ka, jau veidojot rīcībpolitikas, normatīvos aktus un jebkādu administratīvo regulējumu, ir jāṇem vērā paredzamais iegūstamais rezultāts, ko iegūst iedzīvotājs, nevis citas pārvaldes institūcijas. ${ }^{61}$ No labas pārvaldības perspektīvas jebkura valsts veidotā rīcíbpolitika ietver tālredzīgu, uz nākotni vērstu skatījumu un rīcībpolitikas izstrāde ir balstīta uz pierādījumiem. Šajā kontekstā iedzīvotāju draudu uztvere, to intensitāte ir nozīmīgs drošỉbas politikas pilnveides pierādījums. Labas pārvaldības kontekstā daudz uzmanības tiek pievērsts iestāžu savstarpējai koordinācijai un spējai vienoties par koordinētu rīcỉbu ārkārtas situācijās. ${ }^{62}$

Vienlaikus labas pārvaldības elementi pētījumā tika uzlūkoti kā netiešie/ fona indikatori, kas ir saistīti ar drošības vidi un var iedarboties uz personas neapmierinātîbu un diskomfortu (piem., normatīvo aktu izmaiṇu biežums). ${ }^{63}$ Pārvaldības indikatori kā netiešie vai fona indikatori, ilgstošā periodā negatīvi iedarbojoties, var ietekmēt drošības uztveri. Tajā pašā laikā drošîbu tieši ietekmējošie indikatori (piem., drošība uz ielas vai bailes palikt bez darba) ir saistīti ar drošību un pastāvīgi iedarbojas uz drošības uztveri.

Tādējādi, balstoties uz teorētiskām nostādnēm par labu pārvaldỉbu, pētījumā sākumā tika noteikti nozīmīgākie labas pārvaldības elementi, kas atspoguḷo visu plašo pārvaldības jautājumu spektru:

- pārvaldības sistēmas stabilitāte, prognozējamība, pēctecība;

- plānošanas ilgtermiņa pieeja - ilgtermiņa redzējums;

- reformu jēgpilnums - ieviešanas efektivitāte;

- caurskatāmība;

- normatīvo aktu izmaiņas un to biežums;

- ierēdṇu profesionalitāte;

60 World Health Organization. Governance for health in the 21st century. 2012.

61 Ibid

62 Ibid.

63 Cole, G. A. (1997). Personnel Management: Theory and Practice. London: Greener Books, p. 78. 
- informētîba, kā rīkoties X stundā, preventīvās rīcībpolitikas veidošana;

- iestāžu darbības koordinācija.

Tālākajā izpētē šie pārvaldības elementi tika piemēroti drošỉbas sektoriem, kas savukārt secīgi veidoja pamatojumu interviju jautājumiem sarunās ar pašvaldību darbiniekiem un iegūto datu analīzei, salīdzinot ar iedzīvotāju drošỉbas uztveres rezultātiem. 2. tabulā atspoguḷoti pārvaldības indikatori atbilstoši dažādiem drošǐbas sektoriem.

Piektajā solĩ izvēlētas pašvaldības, kurās tika veiktas fokusa grupu intervijas. Fokusa grupu intervijas tika realizētas Ādažos, Daugavpilī, Gulbenē, Jaunjelgavā, Liepājā, L,audonā, Madonā, Rīgā (divas), Rēzeknē, Talsos. Fokusa grupu norises vietas bija izvēlētas tā, lai nodrošinātu plašu reǵionālo pārstāvniecību, kā arī bija nodrošināti dažādi geoogrāfiskie, sociālpolitiskie un ekonomiskie konteksti. Starp izvēlētajām apdzīvotajām vietām ir gan galvaspilsēta, gan republikas pilsētas ar pilsētu domēm un mazpilsētas ar novadu domēm, gan ciems, kurā darbojas pagasta pārvalde. Fokusa grupu diskusiju mērķauditorijas bija veidotas tā, lai maksimāli tiktu nodrošināta dažādu sabiedrības pārstāvju klātbūtne kā demogrāfiskā, tā arī ekonomiskā, sociālā un citās dimensijās. Tajās piedalijās visu vecumgrupu (sākot no 18 gadu vecuma) dažādu dzimumu pārstāvji ar atšķirīgu izglìtības līmeni, sociālo statusu un nodarbošanos, etnisko un religisko piederību. Katrā grupā bija ne mazāk kā astoṇi un ne vairāk kā 15 dalībnieki. Fokusa grupas moderēja šîs monogrāfijas autori, stingri sekojot pētijumā noteiktajam analīiskajam ietvaram un no tā izrietošajai pētnieciskajai log̣ikai. Fokusa grupu intervijas ilga ne vairāk kā pusotru-divas stundas un ne mazāk kā stundu.

Sestajā solī, balstoties uz iepriekš pamatotiem un izvēlētiem labas pārvaldỉbas elementiem un drošǐbas sektoriem atbilstošiem indikatoriem, veiktas intervijas ar visu to pašvaldību darbiniekiem, kurās iepriekš veiktas fokusa grupu intervijas ar iedzīvotājiem. Lai iegūtu salīdzināmus rezultātus, sākotnēji analizēti fokusa grupu dati katrā no pašvaldībām, izceḷot katrā no tām trīs nozīmīgākos draudu veidus, kurus nosaukuši un apsprieduši iedzìvotāji. Šie prioritārie apdraudējumi bija atskaites punkts, vērtējot pašvaldības darbinieku attieksmi pret tiem. Izpētes gaitā svarīgi konstatēt, vai pašvaldības darbinieku minētie riski un apdraudējumi sakrīt ar iedzīvotāju subjektīvi uztvertajiem. Pēc šìs informācijas ieguves pētỉjumā jānoskaidro, vai pašvaldības līmenī tiek veiktas darbības cilvēkiem svarīgajos sektoros un vai tiek vairota vai mazināta viṇu drošumspēja. Pašvaldības pārstāvju attieksme tika mērìta, realizējot padzị̣inātās, daḷēii strukturētās intervijas. Interviju laikā tika uzdoti jautājumi, kas ḷāva identificēt pašvaldības darbinieku skatījumu uz iespējamiem apdraudējumiem lokālajām kopienām, kas dzīvo pašvaldībās, to attieksmes pret katru 
2. tabula. Pārvaldības indikatori drošības sektoros

\begin{tabular}{|c|c|c|c|c|c|c|c|c|}
\hline 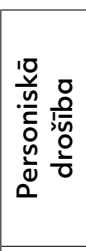 & 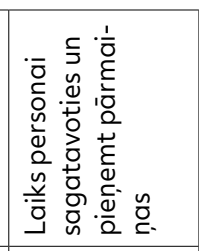 & 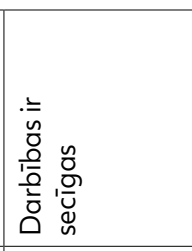 & 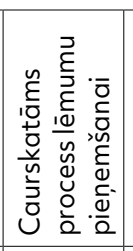 & 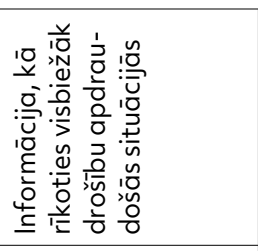 & 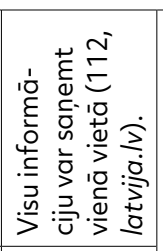 & \multirow{7}{*}{ 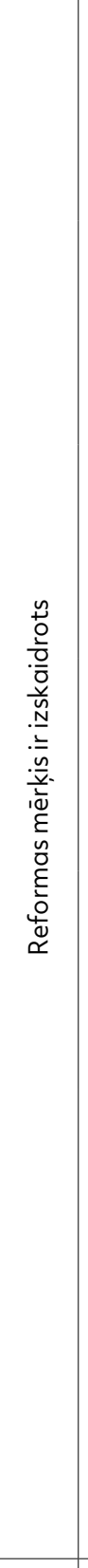 } & \multirow{7}{*}{ 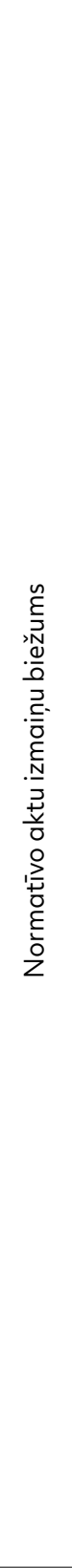 } & \multirow{7}{*}{ 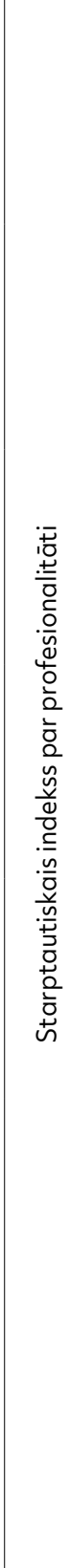 } \\
\hline 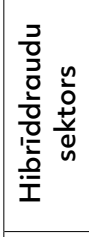 & 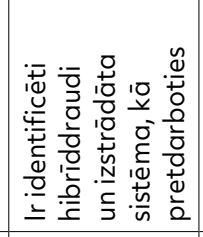 & 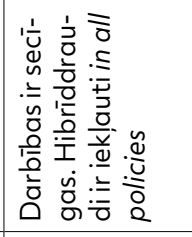 & 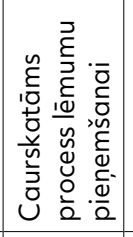 & 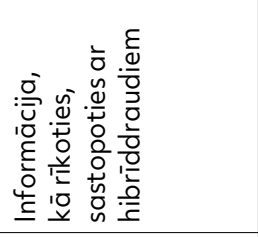 & 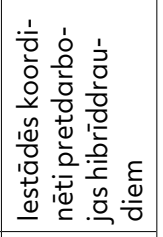 & & & \\
\hline 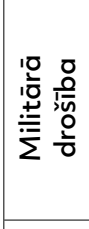 & 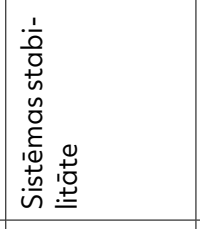 & 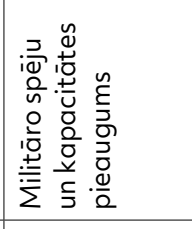 & 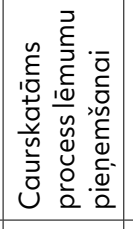 & 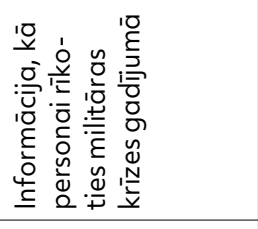 & 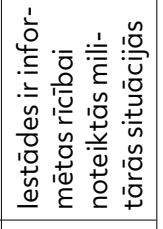 & & & \\
\hline 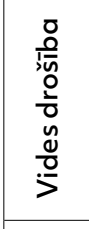 & 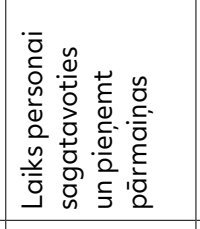 & 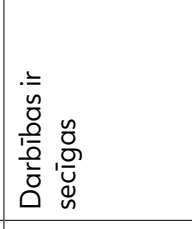 & 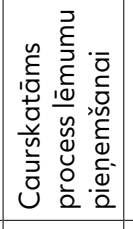 & 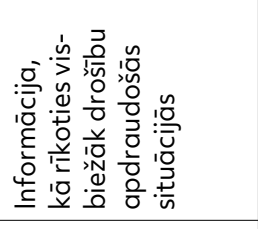 & 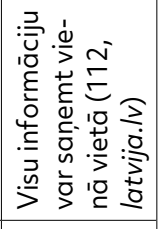 & & & \\
\hline 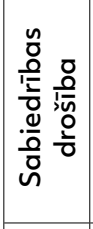 & 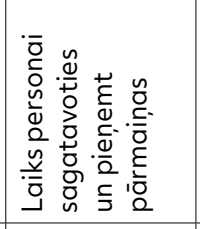 & 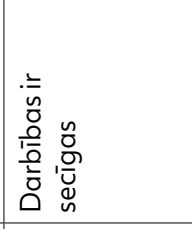 & 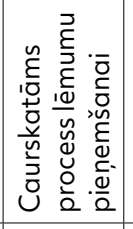 & 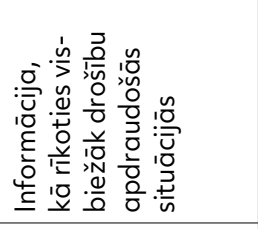 & 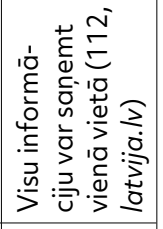 & & & \\
\hline 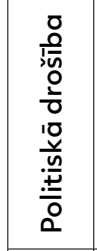 & 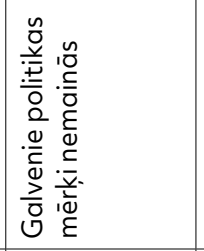 & 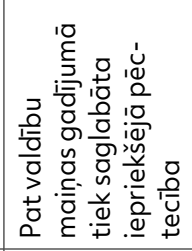 & 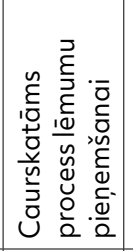 & 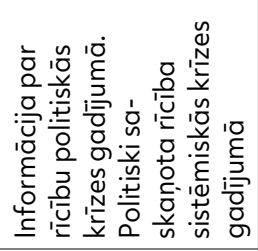 & 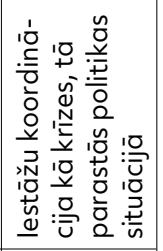 & & & \\
\hline 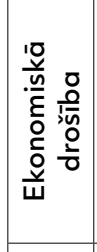 & 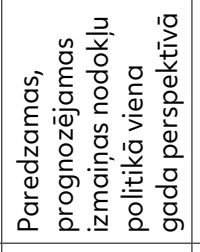 & 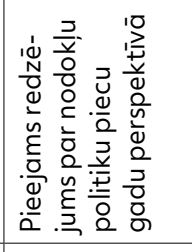 & 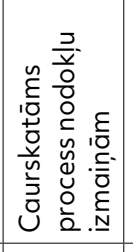 & 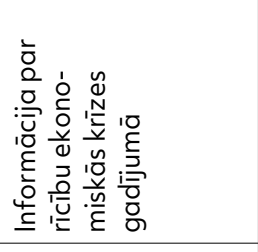 & 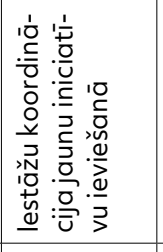 & & & \\
\hline & 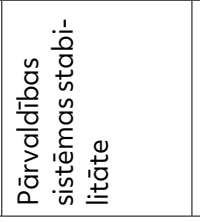 & 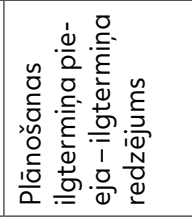 & 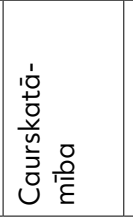 & 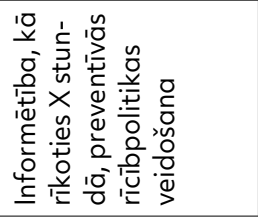 & 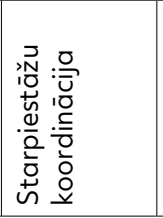 & 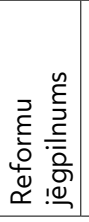 & 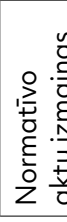 & 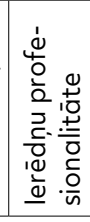 \\
\hline
\end{tabular}


no iedzīvotāju prioritizētajiem draudu veidiem fokusa grupu interviju laikā. Tāpat arī intervijās tika noteikts, vai pašvaldības darbinieki pieškirir vietējai pašvaldībai lomu draudu novēršanā un kāda tā ir, kā arī tika noskaidrots, kā tie vērtē vietējo un nacionāla līmeņa pārvaldes institūciju sadarbību. Lìdzās intervijām tika analizēti pašvaldības stratēgiskās plānošanas dokumenti un normatīvie akti, kas l̦āva ieskatīties pašvaldību realizētajās rīcībpolitikās draudu novēršanas kontekstā.

Pētījuma sestais un noslēdzošais solis ir saistīts ar secinājumu un rekomendāciju izstrādi, kuru veidošanā ir piedalījušies visi iesaistītie monogrāfijas autori.

\section{Secinājumi}

Lai arī drošîbas teorētisko un praktisko aspektu pētī̌sanai Latvijā un pasaulē ir senas tradīcijas, pēdējās desmitgadēs pieaugušo apdraudējumu un risku klāsts turpina piegādāt zinātniekiem un politikas veidotājiem arvien jaunus izziņas laukus. Spēju veikt visaptverošu un teorētiski pamatotu drošības situācijas analīzi ietekmē un arī kavē apdraudējumu avotu savstarpēja pārklāšanās un dinamiska transformācija. Piemēram, kādas sabiedrības grupas šķietami īslaicīga neapmierinātîba ar politisku lēmumu var pāraugt dusmās, kas izpaužas nemieru ierosināšanā, ko uzkurina sociālie mediji, un rezultātā šo situāciju izmanto nedraudzīgi ārvalstu spēètēàji. Šo situāciju varētu raksturot kā hibrīddraudu tālāku "hibridizāciju". Cilvēku emocijas, kas veidojas drošības uztveres rezultātā, atstāj iespaidu uz rīcībpolitiku formulējumu, pieņemšanu un ieviešanu pašvaldību un nacionālā līmenī, kā arī uz indivīdu personisko stratēǵiju un noturīguma izstrādi un lietošanu. Jo lielākā mērā valsts un kopienu līmeņa pārvalde reagêe uz iedzīvotāju bažām un bailēm, jo lielāka iespēja izveidot partnerības un sadarbības modeli ikdienas izaicinājumu risināšanā, kurš krīzes un ārēja apdraudējuma apstākḷos kalpo visaptverošās aizsardzības mērķiem. N̦emot vērā, ka drošỉbas subjektīvā uztvere raksturo sabiedrībā pastāvošo attieksmju daudzveidỉbu, tieši fokusa grupu intervijas ir viena no metodēm, kura atklāj iedzīvotājos valdošo emociju spektru. Apkopotie rezultāti un datu puduri no dažādiem Latvijas novadiem var sekmēt tādu rīcībpolitiku ieviešanu, kas atbilstu konkrētās kopienas vajadzībām. Rakstā piedāvātais metodologiskais rāmējums ir izmantots empīiskā pētỉjuma veikšanai un ir nodrošinājis rekomendāciju izstrādei bagātīgu informācijas klāstu, kas atspoguḷots grāmatas noslēgumā. 